\title{
Authority Of Notary In Making Related Act With Land In The Context Of Land Registration Under Paragraph 2 Of Article 15 Of Notary Law
}

\begin{abstract}
Argo Suseno ${ }^{1}$, Sema Ardianto ${ }^{2}$ and Amin Purnawan ${ }^{3}$
Abstract. Notaries in making written evidence in the form of an authentic act, done according to the will of the parties / party attended for otherwise in agreement and in front, so as not to violate the law, and that the will of the parties is done properly and correctly. The aim of this study was to know implementation notary authority in the said agreement to land in the context of land registration in accordance with Article 15 paragraph 2 of Notary law, as well as to find out the barriers and solutions in the implementation of the authority. The method is carried out normative, descriptive specification using secondary data, through literature, then analyzed qualitatively. The results show that (1) the exercise of authority notarized in agreement a blessing to the land in the context of land registration in accordance with Article 15 paragraph 2 of Notary law is done according to the code of ethics of notaries authorized to make the Agreement of Waiver or agreement of transfer of right, obstacles encountered is community refusal to act because of the cost factor and solutions in the implementation of the authority having socialization law on public notary's role in making the act in the context of land registration.

Keywords: Notary, Authentic Documents, The Land Registry.
\end{abstract}

\section{Introduction}

The role and activities of notaries in the legal profession can not be separated from the fundamental issues relating to the function and role of law itself, which is defined as the legal rules governing the life of the community, more broadly the law serves as a means to reform society.

Article 1 (1) of Act No. 2 of 2014 on the amendment of Act No. 30 of 2004 concerning Notary (hereinafter referred UUJN 2014) states that the notary is a public official who is authorized to make the act of authentic and have other authorities referred in this law or by other laws. Public notary's office is said to be due to the notary is appointed and dismissed by the government. In connection with the notary as a public official, in accordance with Article 15 (1) UUJN 2014 said the following:

"Notaries authorized to make authentic act of all acts, agreements, and stated require by legislation and / or required by stakeholders to set out in authentic documents, ensure the creation date of the act, save the act, give grosse, copy and quotes agreement, it was during the making of it not also be assigned or excluded to the official or other person designated by the law ".

As stipulated in article 15 paragraph (2) and (3) UUJN Of 2014, with such authority, notary agreement binding on the parties or those who have the power to make and perfect as evidence. some things should have turned out to support the performance of a notary is not required, especially when viewed from the ability notary in

\footnotetext{
${ }^{1}$ Student of Master Program in Notary Program Faculty of Law, Universitas Islam Sultan Agung emai argosuseno@yahoo.co.id

2 Students of Master of Law, Faculty of Law, Universitas Islam Sultan Agung email semaardianto@gmail.com

${ }^{3}$ Lecturer of Faculty of Law UNISSULA
} 
expressing the will of the parties to an agreement. Not uncommon legal issues related to the notary that problems in implementing language, words and interpretations until the end notary agreement produ.k produce adverse side-facing one.

Notaries in making written evidence in the form of an authentic act, done is merelatir ${ }^{4}$ the will of the parties / party attended for otherwise in agreement and in front, so as not to violate the law, and that the will of the parties is done properly and correctly. The responsibility of the notary in relation to the legal profession in carrying out his position can not be separated from the majesty of the law itself, so it is expected the notary can act to reflect in its service to the community.

The formulation of the problem under study is about how implementation notary authority in the said agreement to land in the context of land registration in accordance with Article 15 paragraph 2 of Notary law? and how obstacles implementation notary authority in the said agreement to land in the context of land registration in accordance with Article 15 paragraph 2 of the Law on Notary and solutions obstacle implementation notary authority in the said agreement to land in the context of land registration in accordance with Article 15 paragraph 2 of Notary law?

\section{Research Methods}

The method used is normative juridical approach. Specifications of this study was analytic descriptivegive a clear picture of implementation notary authority in the said agreement to land in the context of land registration in accordance with Article 15 paragraph 2 of Act No. 2 of 2014 concerning Notary, Data needed in this discussion is secondary data, through the study of literature, especially in Act No. 2 of 2014 concerning Notary. Data was analyzed using descriptive and qualitative approach, the qualitative approach was used to analyze the statistical parameter data.

\section{Results And Discussion}

\subsection{Authority Notary In The Said Agreement To Land In The Context Of Land Registration In Accordance with Article 15 paragraph 2 of the Notary Law}

Notary authorized to make authentic act of all acts, agreements, and resolutions required by legislation and / or required by stakeholders to set out in authentic documents, guaranteeing the creation Act, save the act, give grosse, copy and quote the Act, it was during the making of acts that are not also assigned or excluded to other official or other person designated by law as stipulated in Article 15 paragraph (1) of Act No. 2 of 2014 on the amendment of Act No. 30 Of 2004 About Notary.

In the case of notary is authorized to make an authentic agreement on the land. The authentic act is an act in the form prescribed by law, made by or in the presence of a public official who is authorized to act it in a place where it is made. ${ }^{5}$

Privileges of an authentic act is a perfect proof (vovolleding bewijs full-evident) about what is contained therein. This means that when someone submits an official agreement to the judge as evidence, the Judge shall receive and consider what is written in the act, an event that really has happened and does not judge may order additional evidence. For the transfer of land rights must be made before a notary or Public. For acts that are glued land rights, in fact the special authority of the Public for

\footnotetext{
${ }^{4}$ A.A. Andi Prajitno 2010 Pengetahuan Praktis tentang Apa dan Siapa Notaris di Indonesia Surabaya: Putra Media Nusantara p. 3-4.

${ }^{5}$ Article 1 point 7 UUJN no. 2 of 2014
} 
either authentic documents to:

- Transfer of land rights

- Giving something new rights over land

- Mortgaging land

- Lend to land rights as collateral. ${ }^{6}$

But the shift of its above can be executed before a notary on lands not yet / not glued rights made in the form of the Transfer of Rights with Compensation (HGR) is the transfer of rights to the land and everything that was on the ground should be executed in front of PPAT. But there are times when this Public authority at the request of the parties / party attended made by agreement. What the agreement, set out in the act is actually like what is promised, otherwise by the parties to be seen or heard by the notary, is especially true regarding the date of the act, the signature on the certificate, the identity of those present, and the agreement was done.

As for the pacquisition of land in the procurement of land for the benefit of a private company can be reached by way of transfer of rights over land through purchase or disposal of land rights. When the acquisition of land in land acquisition by the company swasra reached by way of sale and purchase of the privately owned company incorporated as a buyer, but private companies subject areas such as leasehold, with property rights or right to use. When the object of purchase in the form of Ownership then private companies can not purchase the land rights.

In the case of a waiver, a private company may acquire the land, with the granting of compensation, the form and amount of compensation is determined on the basis of an agreement in the consultations between the parties requires land (private companies) with the holders of the land.

\subsection{Barriers Faced By A Notary In the Said Agreement To Land In The Context Of Land Registration}

Barriers faced by a public notary in this case is the refusal of society as holders of the land to waive its right to process the deal takes a long time, in addition to the role over trust land management to head due be regarded even know the origin of the land and assume the cost is cheaper than land management through a notary.

As for the act Waiver of Claims made by the district or both sides by agreement, by notary law is not responsible for the act for which an agreement is the parties themselves or in front of the district and not in presence of but Notaries have the moral responsibility to act, when the agreement is to be legalized or warmerking.

\subsection{Solutions To The Barriers Faced By Notaries In The Said Agreement To Land In The Context Of Land Registration}

Sometimes notary may refuse to act in the case of manufacturing: ${ }^{7}$

- When prompted to create a Notary Minutes for advertisement purposes or purposes.

- When the notary knows that the act required by the parties to the conflict with the laws and regulations in force and the actual reality.

Similarly, the responsibility of the agreement Waiver of Claims, where the certificate can be used as evidence to ensure a legal event in order to avoid a dispute at a later

\footnotetext{
${ }^{6}$ Effendi Perangin-angin 2013 Praktek Permohonan Hak Atas Tanah Rajawali Press Jakarta p.34

7 Bustami Chairani 2002 Aspek-aspek Hukum Yang terkait Dalam Akta Perikatan Jual Beli Yang

Dibuat Notaris Dalam Kota Medan Jurnal USU Medan p.91
} 
date, the agreement must be made such that any who wish proved that it can be seen easily from the agreement. While the Act Waiver of Claims made by the district or both sides by agreement, by notary law is not responsible for the act for which an agreement is the parties themselves or in front of the district and not in presence of but Notaries have the moral responsibility to act,

Before making Relinquishment Agreement of Indemnity With a notary must check the validity and completeness of the woods and papers relating to land ownership pembukitian so it can be used as a condition for pushing an agreement. Regarding the accuracy of the contents of the letters examined notary can not test it materially to the existence of the existence of the land in question, in other words the notary did not go to the place where the land is situated or to see the boundaries of the land within the meaning of these letters, Notary simply look at the evidence that was given to him by letters.

\section{Conclution}

- Authority notary in the said agreement to land in the context of land registration in accordance with Article 15 paragraph 2 of the Law Department. carried out in accordance with the terms and conditions of registration of land, while the private companies can obtain land rights through the process of disposing of the land rights of the holders of land rights and land rights be abolished and the land returned to state land, more private companies are obliged to apply for the grant of rights the land released to the Chief land Agency of the Republic of Indonesia through the head of the District land Office / municipality.

- Barriers implementation notary authority in the said agreement to land in the context of land registration in accordance with Article 15 paragraph 2 of the Law Department. the doubts people to do an agreement relating to the land registry to the public because of the cost of other people's surrender to the district land registration process. so with the release of land rights.

- Solutions to obstacles implementation notary authority in the said agreement to land in the context of land registration in accordance with Article 15 paragraph 2 of the Law Department. in the case of the release of land rights, the need to agree in consultation beforehand between the holders of land (owners of land rights) to the receiver release land rights are private enterprises witnessed by village (district) in order to avoid disputes in the future, in addition to the necessity of always request made Certificate of no Cross Kind (also called SS) issued by the Leader and amplified by the district in which the land is located, the contents of this letter explains that on the land to be sold is not disputed by any party.

\section{References}

[1] A.A. Andi Prajitno 2010 Pengetahuan Praktis tentang Apa dan Siapa Notaris di Indonesia, Surabaya: Putra Media Nusantara.

[2] Bustami Chairani 2002 Aspek-aspek Hukum Yang terkait Dalam Akta Perikatan Jual Beli Yang Dibuat Notaris Dalam Kota Medan Jurnal USU Medan.

[3] Effendi Perangin-angin 2013 Praktek Permohonan Hak Atas Tanah Rajawali Press Jakarta.

[4] UUJN No. 2 of 2014 